\title{
Turkish Foreign Policy Trends Since 2002
}

Wan Kamal Mujani

The National University of Malaysia

Email: inamal@yahoo.com

Ahmed Y.M. Alahmed

The National University of Malaysia

Email: ahmed17w17@yahoo.com

\section{Eeman Mohammed Abbas}

The National University of Malaysia Email: anar_111@hotmail.com

\section{Doi:10.5901/mjss.2015.v6n4s1p400}

\begin{abstract}
In recent years, the Turkish new foreign policy has caused a lot of debate in the field of politics as many researches and analysis centres have kept busy discussing the new Turkish policies. It has also drawn the attention of the big countries that are concerned about the changes in the region as they may affect their interests in it, especially when Turkey has gone with full power and capability towards the East trying to play a vital role. It is worth mentioning that Turkey has attempted over many years to enter the European Union and fulfilled most of the required conditions for that purpose. However, such attempt still encounters many obstacles with regard to joining the European Union. Due to such difficulty, Turkey has directed its political and diplomatic attention towards the region in an attempt to restore its leadership position through playing an essential role in the regional conflicts and initiating solutions and suggestions for peace. The new policy is based on the theory of zero problems raised by the Minister of Foreign Affairs, Dr. Ahmed Oglu, thus it strives to end the territorial disputes with neighbouring countries to achieve greater stability and focus attention and activity on stabilizing the foreign relations. Turkey has also struggled to overcome the internal problems that limit its outward growing role.
\end{abstract}

Keywords: the policy of zero problems; multidimensional policy; harmonious policy; multiplicity of relations and trends;

\section{Introduction}

The Turkish politics in the Arab region has played an important role particularly with Islamic and Arabic events, where the new Turkish politics becomes more dependent on relations and does not move only in one direction according to its geography and history. This policy contrasts with the unilateral policy adopted by Turkey during the Cold War. And with the development of international relations and interest between nations, and after choices have become more complex and no longer possible to adopt a single direction, therefore diversity becomes the best choice for new developments in foreign relations with the countries of the world, particularly the neighboring countries to Turkey (Oglu, 2010).

Therefore, the new vision of the Turkish foreign policy, as seen by the leaders of the Justice and Development Party, enables them to perform a new role in the regional circle; a role different from the roles carried out previously. This is an objective rational vision based on long term strategic planning to achieve the utmost benefit of Turkey's abilities. The leaders of the Justice and Development Party consider this political foreign vision as lively, dynamic, decisive and rationally calculated. In this regard, the Prime Minister, Ordoghan, states "the change is necessary to keep pace with the changing world. This explains the government's action in giving the priority to a new vision in the foreign policy for the sake of pushing Turkey to the future and transforming it to an influential world power" (Litim, 2013).

\section{Turkish Foreign Policy}

After 2002, Turkey started to build a new strategy for its foreign political relations in an attempt to get benefit from its strategic location and historical inheritance. The Foreign Minister Dr.Ahmed Oglu specified the aspect of Turkish foreign 
policy in five key principles:

\subsection{Achieving the balance between security and democracy}

The legality of any political system derives from its ability to provide security for its citizens, and security must not be at the expense of human rights and freedoms. Besides, the lack of balance means the weakness of the state to affect its surroundings areas, and the state may turn to autocratic regimes under the pretext of security reasons. However, this balance is considered a cultural and political matter.

Therefore, the government of the Justice and Development Party seeks to achieve and guarantee freedom to its citizens without any negative consequences threatening the Turkish national security internally or externally. Such strategies participated in making a number of political, economic, cultural and social reforms concerning the status of the minority groups such as the Kurds and Alawites. This step has added to the popularity of the Justice and Development Party among such minorities. Such policy springs from Turkey's attempt to establish a strong link between freedom and security. The government has thus headed toward achieving freedom and democracy simultaneously. It has a view that achieving freedom must not be at the expense of security; both should be achieved together. Thus, the Party avoids the political discourse that adopts a racial or religious ideology that could cancel the other. The Party keeps a similar pace to all the Turkish citizens who are seen to be equal regardless of gender, race, religion, thought or political views. The Party also sees that the Turkish Republic is based on secularism, democracy, law, social and civilization processes, freedom of thought and justice of chance.

\subsection{Zero policy of problems with neighboring countries}

Turkey has made great efforts in this context, and has been successful for many years by achieving a major economic connection with neighboring countries. For example, strengthening the Turkey's relation with Bulgaria after it joined the European Union. In addition to that, Turkey has succeeded in addressing the risks related to Iraq, where the Iraqi government understood the Turkish operations and position against PKK and was considered a common enemy (Oglu, 2010).

It is possible to say that this principle was successful for a limited period, but the zero policy of problems is not valid anymore, after the recent development and revolutions in the Arab world (or what is called Arabic Spring) that led to the collapse of the established political regimes in the Arab countries and initiate new regimes that have changed the shape of international relations all over the region, and in particular the foreign policy of Turkey that has been strongly affected by the recent development in the region since 2011.

Turkey has changed the relation with neighboring countries dramatically, for example, with Syria the relation has strained largely after the dispute between the two countries has intensified more than ever because of Turkey's support for Arab revolutions and the support to give the Arab peoples their right to self-determination and their right to select a new government to represent them, also because of its opposition to the situation of killing and repression on the Syrian grounds. In addition to that, its relation with Iran the strategic and historical ally of Syria has become worse, and therefore Turkey has opposed Iran strongly because of the full support from Iranian officials to extend the life of the regime in Syria and the way that Iran has defended this regime till the end of its survival. Al-Mada newspaper reported on April 22, 2013 that Aladdin Broujroda the Chairman of the Committee of Foreign Affairs and National Security in Iran's Parliament, after his meeting with Bashar al-Assad, he said that "the best option is the survival of the current president Assad until summer of 2014. All these developments have increased the international pressure on Turkey in order to stop Turkish interference and effect on the events and revolutions in the Arab World.

\subsection{The effect on inner and outer regions of the neighboring countries}

The Turkish government has started to influence the neighboring regions since its arrival to power. The Turkish Prime Minister, Ordoghan, directly met with the Arab ambassadors after the election of 2002. He said that Turkey wanted to revive the relations with the Arab and Islamic World as soon as possible and in all political and economic fields. He also said that Turkey's relations with the neighboring countries and the world are good. Therefore, Turkey has become active in all activities regionally and internationally. Istanbul has become a center for international conferences, where many meetings and conferences are held. Such policy has resulted in the Turkish increase of activity at the level of the Islamic World, where a Turkish academic was elected as a general secretary for the Islamic Organization. Such event is the first in which a Turkish personality occupies such a position. 
Turkish political interest is the biggest among the Balkan countries as well as in the Caucasus region and Central Asia. Turkey has focused a lot on the Balkans, including Bosnia and Herzegovina, Albania, Kosovo, Bulgaria, Montenegro, Croatia, Serbia, Mecedonia. Turkey has also enjoyed close relation with Azerbaijan and Georgia in the Caucasus region. Besides, it has stepped up its efforts in the Middle East (Oglu, 2010) and become an owner of communication channels that enable Turkey to follow all the developments in the region as soon as possible in light of high technologies, and not only at the official level, but also in the domestic level. Turkey has shown an active role towards the events in the Arab world and in particular the Palestinian matter, which has taken the main interest and popular support by the Turkish people and the government as well. This attention reached its peak in 2010 when Turkey sent an aid ship to Palestinian people under the authority of Turkey, which was known as the fleet of freedom heading to Gaza, in order to participate in the lifting effort of the blockade imposed on Gaza at that time. However, Israel intercepted the fleet and killed a number of Turkish participants, and following this incident a political crisis erupted between Turkey and Israel (Al-Brusan, 2010).

\subsection{The multidimensional foreign policy}

The meaning of multidimensional policy is that Turkey's foreign relations are not competing well with the key international players in the region and it is not a substitute for them, but rather complementary to them. However, through this policy, Turkey seeks to highlight its strategic relations with the United States in the structure of its connection to the NATO, under the concept of bilateral relations. In addition to continuing attempts to join the European Union, where Turkey has sustained open channels of communication, and there has not been stalemate in bilateral relations.

This varied policy is associated with the geographical location of Turkey that borders with lively areas in the world. Therefore, the leaders of the Justice and Development Party have sought to develop a new diplomatic style in their foreign policy that seeks balance with all foreign powers and uses a special way with each power in a way that suits each one of those powers. Moreover, the Turkish foreign policy developed a constant dynamic diplomacy represented in coming together with as many people in charge as possible at all levels in other countries and continents. Such diplomacy depends on three main ways, namely a balanced discourse that serves the other, keeps the required balance between rights and duties; focus on the mediatory role to achieve as much compromise and rapprochement as possible between the region's countries; and increase of supportive power so as to make Turkey a center for the countries that seek peace and political, economic and social reforms.

\subsection{The harmonious diplomacy}

Turkey diplomatic performance has developed significantly in recent years comparing to 2003. The international organization has become more active and Turkey has hosted conferences and international summits such as NATO summit and the summit of Organization of the Islamic Conference, also several international forums. Turkey has acquired more influence in international organizations. Turkey then has followed open policy on Africa since 2005 and participated in Arab foreign ministries meetings. In addition to that, Turkey signed a special agreement with the Arab League after a meeting of Iraq's neighbors in Istanbul in November 2, 2007. This agreement stated to establish organizational relations between the neighboring countries of Iraq and form Arabic-Turkish dialogue (Oglu, 2010).

This advanced and harmonious diplomacy adopted by Turkey has led to the rise of its position and created a strong reputation of Turkey as a peace maker and a security keeper in the region. In addition to that, Turkey has emerged as a country which gives democracy and freedom high priority, and deals with internal security problems with high efficiency. Therefore, Turkey always aims to act as an intermediate negotiator in solving international problems using global connections and agencies; and this is another proof of the transformation of the Turkish role from central country to international power.

In this context, the Foreign Minister Ahmed Oglu (2010) said stated that this shift in foreign policy was the result of the performance of all parties involved in foreign policy, and not only the policies of the state, but also as a result of the activities of civil society and business organizations, where everyone works according to a new vision, in a form of harmony and agreement between the main strategy of the state and the strategies for small companies and individuals, institutions and civil society organizations as well.

And with regard to the perspectives and motivations of this new policy and the adopted philosophy, Professor Ibrahim Kalin, the adviser of Prime Minister Recep Tayyip Erdogan and the Deputy Chairman of the Foreign Relations Committee of the Justice and Development Party, referred to this point and philosophy in a speech in the Institute of Turkish Studies and the Institute for Regional Studies in Washington, as it was stated in his speech that Turkey 
commenced from a deep understanding of the reality of the new international relations. He added that Turkey is no more depending on one direction in the foreign policy but also depending on multiple relations and direction. Turkey definitely moves according to its comprehensive national interest (economical and security), and the Turkish foreign policy emanates from four main principles, which are (security, freedom, prosperity, and indentify).

These are the key principles that the leadership of the Justice and Development Party adopted in its foreign policy. This is evident in the Party's success in establishing a big change in the behavior of the Turkish foreign affairs politicians. It is a party unlike other traditional parties. It could establish harmony between the political values and achievement of its objectives. It has also been able to give politics its genuine meaning in Turkey. The Party could regain the central role of Turkey in the region as Turkey had ruled the region for over four centuries. The Turkish government through the leadership of the Prime Minister, Ordogan, and the Minister of Foreign Affaris, Ahmed Dawood Oglu, have managed to reactivate the Arab role in the region in a way that avoids troubles or disputes with the superpowers. Oglu considers Turkey of a geographical and historical position that obliges it to be the country that should not be sufficient of establishing stability, security and system for itself alone, but rather it should make all those available to all the neighboring countries. This paves the way for extending the field of regional cooperative projects that satisfy the Turkish interests.

There have been many factors that contributed to changing the Turkish role and developing the Turkish foreign policy as shown above. Some reasons are associated with the Middle East region and the leadership vacuum that the region witnessing especially after the occupation of Iraq. Turkey realizes that it has a regional role to play that will lead to making great improvement in its status in the world. In addition to the Arab World (Middle East) through which Turkey can perform an active key regional role without making any clash with the global powers, this status will help Turkey to achieve its big dream to join the European Union (Litim, 2013).

There are other reasons for this success enjoined by the Turkish foreign policy which is due to the style adopted by the Party's leadership. In this regard, Emrullah Isler, The Turkish Deputy Prime Minister, considers that truth is one of the main factors of the new Turkish foreign policy despite its severity. Turkey has abandoned the traditional dual style in the foreign relations among countries. This new style increased the Turkish validity with the other sides and strengthens its stances.

The economic factor has gained a lot of attention in the policy of the Justice and Development Party since its arrival to power. Turkey has set the foreign economic plan based on its new comprehensive strategy, something that has gone as planned. Part of this plan is exerting endeavors to join the European Union and heading toward establishing new partnership with the Arab World. Such step could extend economy and partnership in the region as well as establishing a new economic field in the Central Asia after the collapse of the Soviet Union. This latter attempt would give the Turkish policy an oriental characteristic.

\section{The Quest for Leadership}

Turkey is pursuing all its power to take a leadership position in the region, in an attempt to restore the great past historical position of Turkey, when the latter was a central state which represented the major and influential state in various political events in the regional and other parts in the world as well. According to that Turkey has been playing a vital role in regional conflicts and endeavoring to provide solutions and suggestions for making peace and putting an end to regional conflicts. The Palestinian case has taken the highest priority and attention because it has been the main foreign issue in the region. Therefore, Turkey today is more influential with the current political conflicts and events due to the development of its political decision with regard to critical matters such as the Arab-Israeli conflict, and hence its relations with some countries have been changing and tiding frequently. However, the recent development of Turkish political position and rise of Turkey as a major political and military power in the region has increased the popular support for Turkey, especially in Arab countries as Turkey stood beside the revolutions in Arab countries and defended people's right to self-determination according to a survey achieved by Turkish association TESEV.

It is clear that between October 19-December 15 in 2011 and as published by Al-Jamhuriya newspaper in Lebanon (issue 199) dated February 4, 2012, a survey including 2323 participants from 10 countries including Arab countries, where $70 \%$ of the participants agreed that Turkey should play a major role in the region and that it has become more influential in the current time. And with regard to Arab-Israeli conflict, $75 \%$ of the participants agreed that Turkey could play a vital role as an intermediate negotiator in this conflict, where $78 \%$ of the participants' opinion about Turkey was positive and agreed to its new foreign policy.

And with regard to democracy and human rights, $61 \%$ of the participants agreed that Turkey is a good example of democracy and they predicted that Turkey might be an international economical power in the future. Miss Ghmazah 
Jawshan, a specialist researcher in Middle East and North Africa affairs, who works in Strategic and International Researches Organization said that "this survey showed that the interest of Turkey is to play a positive role in the region".

In a report published by (Stratfor) the Strategic Forecasting, Inc., in the United States on February 2, 2009, the Director of Stratfor George Friedman believed that Turkey has a deep vision for being a Muslim country with responsibilities beyond ensuring the national security, and it can rely on this vision. Thus, he thought that the United States in the current time needs Turkey more than the need of Turkey to the United States.

In according to this vision George Friedman predicted that Turkey could deliver its power outside the national boundary to support Muslims and to retain its powerful Navy, and this vision is extendable. In addition to that, George Friedman agreed that Turkey in the Muslim world is one of the five fundamental powers that has Economic and military capabilities sufficient to influence externally beyond the borders of Turkey (Friedman, 2009).

According to Ahmed Oglu, Turkey has a new position in the world after the events of September 2001. This new position has two bases; the intellectual basis, and the geographical basis, where in terms of geography Turkey is strategically located in the world, and it is a central country with multiple regional identities. Therefore, the Turkish policy could not be reduced to a unique attribute. However this regional and multiple structures allow Turkey to play in many areas and to be more influential and powerful. Dr. Ahmed Oglu considered Turkey as a perfect country because of its geographic location because it is an Asian and European country at the same time and near to Africa. This means that Turkey is not an ordinary country and should not identify itself from a defensive position. Moreover, Turkey is not a country located at the edge of Islamic and European world. Adding to that, the cultural and historical heritage of Turkey has made it one of the central attraction spots in the world throughout history.

\section{Growing Economic Influence}

The economic power of Turkey is increasing every day, and now it is considered as the most developed country in this field among the countries of the region. Paule Salem the manager of Carnegie Center in Middle East in Lebanon stated that this century maybe the century of Turkey because it is the only country which is moving in the right way towards the future, and he argued that new Turkish people have understood how democracy could be effective in the region, and how they could apply economic activities in the 21th century, and combine between individuality and groups who have common interest in the same community in the Arab region (Salem, 2010).

The economic statistics show the continuous rise in trade volume between Turkey and the country in the region, and this was found by the Turkish research center in Ankara after issuing a report about that illustrating a big progress in Trade volume with the region countries. Besides, the export volume to the Middle East countries has increased to 3.9 billion USD in 2000 and to 23.60 billion USD in 2010.

The researcher Mohammed Saeed Al-Adhab referred that Turkey has transformed to what is called a trading country, where GDP in 1975 was 13\%, but in 2008 it increased to 45\%, and the export value increased to 334 billion in 2008 compared to 19 billion. The Organization for Cooperation and Nutrition stated that Turkey is able to achieve a high economic growth beyond expectations and more than all the nation members in this organization during 2010, which entitles Turkey to rank third in the world after Singapore and China. The US aid foundation estimated the market value of Turkish construction in the region to be equal to 2.87 billion USD.

The Turkish foreign trade volume has doubled since the year 2002, when the Turkish economy has achieved growth rates higher than global averages as the annual average was 5.3\% during the period from 1980 to 1990 and 4.5\% during the period 1990-1998. The Turkish economy has shrank between 1999 and 2001 because of the crisis faced by Turkey, but after the year 2002, Turkey has achieved great development, reaching the speed of domestic growth of production in 2005 of $7.4 \%$ and in 2006 it reached $5.9 \%$, whereas it increased to $12,7 \%$ in 2008 .

On the other hand, The Turkey Today newspaper reported that the Turkish Prime Minister Recep Tayyip Erdogan said in a speech during a meeting of Justice and Development Party in Ankara on February 19, 2013 that the government would pay another debt of the International Monetary Fund by May 14, 2013, and thus would end the foreign debt file, which lasted for ten years, and pointed out that Turkey will become a payable country to the international Monetary Fund, which requested a loan of five billion USD, and revealed that the cash reserves in the central bank amounted to more than 125 billion USD.

The solid activities of the Turkish economy have shown the interest of Turkey to become a powerful country in the region in the political and economic level, which makes Turkey a central county that attracts global attention, which cannot be override by the great powers who have had strong domination and influence in the Middle East for a long period. Nowadays, Turkey is still trying to join the European Union, and spending all efforts to fulfill the requirement of joining the European Union. However, the Turkish interest in Europe has not prevented Turkey from focusing on the 
region and taking a pivotal role there. This was confirmed by the Turkish Prime Minister Recep Tayyip Erdogan, who declared that regretting the past years when Turkey's interest was being focused only on the internal affair and leaving the desired role that Turkey should have taken due to its natural position in the region, which Turkey deserves as it is a big country and has great hopes (Aljazeera.net, 2013).

\section{Concluding Remarks}

Turkey is one of the key countries in the region, and its foreign policy in recent years has developed dramatically, which has made it the focus of many studies and raised many questions as well. Turkey has used all its power and potential to play a pivotal and central role in the region, as well as all its political and economic potential for the sake of acquiring a bigger role. Turkey becomes more dependent on the policy of multiple relations and open policy, but not on the policy of one direction, without stopping to spend all efforts to fulfill the requirement of joining the European Union, and building strong economic and political relations with all countries in the Arab region.

Turkey has been transformed over the past ten years from being a debtor to International Monetary Fund to becoming a creditor country. Moreover, the reserves of the Turkish Central Bank have increased significantly. In addition to that, the Turkish foreign policy has been consistent with the recent development in the Arab region, where the multiple policy adopted by Turkey has been successful and not conflicting, only because it is an original and right policy.

\section{References}

Al-Brusan, Ahmed. (2010). Turkey and Israel after the Attack on the Freedom Fleet. Journal of Middle Eastern Studies, $13,15-27$.

Friedman, George. (2009). Ordoghan's Revolution and the Future of Turkish State. Al-Mostaqbal al-Arabi, March: 129.

Litim, Fatiha. (2013). Turkey and the New Regional Role in the Middle East. Al-Mofaker, 30 (April), 211.

Oglu, Ahmed Dawood. (2010). Features of Turkish Foreign Policy in a Changing Region and in the World. Trans. Fatimah Ibrahim alManofi, Ankra: Rouya Turkiyyah.

Salem, Paul. (2010). Turkey is the only country in the Middle East, which is moving towards the future. Retrieved May 24, 2010, from carnengie-mec.org.

Al-Jazeera.net. (2013). Retrieved December 12, 2013, from http://Aljazeera.net/portal. 